\title{
The Effect of Somatostatin on the Response of GLI to the Intraduodenal Administration of Glucose, Protein, and Fat*
}

\author{
H. Sakurai, R.E. Dobbs and R. H. Unger \\ Veterans Administration Hospital and Depts. of Internal Medicine and Physiology, the Univ. of Texas Southwestern Medical School, \\ Dallas, Texas
}

Received: April 2, 1975, and in revised form: June 12, 1975

\begin{abstract}
Summary. The effects of somatostatin on GLI release during the absorption of intraduodenally administered glucose, casein hydrolysate and longchain triglycerides were studied in conscious dogs. Whereas, after an intraduodenal glucose load, GLI rose promptly in saline-infused control experiments to a peak of $5 \mathrm{ng} / \mathrm{ml}$ (SEM \pm 4 ) in 60 minutes, significantly lower values were observed during somatostatin infusion $(\mathrm{P}<0.025-0.05)$. A similar reduc-
\end{abstract}

tion in the magnitude of the GLI response to intraduodenally administered casein hydrolysate $(P<0.05)$ and fat $(\mathrm{p}<0.05)$ was observed.

Key words: Glucagon-like immunoreactivity (GLI), glucagon, insulin, triglyceride, glucose, fat, protein meal, somatostatin.
Somatostatin [1] has previously been shown to inhibit the release of growth hormone [2], thyrotropin $[3]$, insulin $[4,5]$, glucagon [6,7], and gastrin [8]. The present sudy was designed to determine the effect of somatostatin on the release of glucagon-like immunoreacitivity (GLI), a polypeptide of as yet undetermined function, that is most abundant in the post-duodenal small intestine. It is released during the absorption of glucose [9], long-chain triglycerides [10], amino acids [11], and certain salts [12]. Although sharing certain of the biologic and immunologic characteristics of true glucagon, GLI is clearly a different molecule [13].

\section{Materials and Methods}

Thirteen healthy mongrel dogs, weighing between 19 and $23 \mathrm{~kg}$, were used in groups of 4 or 5 animals for the various experiments. Two days before an experiment, the animals were operated on under Nembutal anesthesia and a polyethylene catheter was inserted through a midline abdominal incision into the

* Supported by NIH Grant AM 02700-16; Pfizer Laboratories, New York, New York; Bristol Myers Company, New York; Mead Johnson Center, Evansville, Indiana; Rabbit 30K Fund; Dr. Karl Thomae GmbH, Germany; Hoffman-LaRoche, Inc., Nutley, New Jersey; Hoechst Pharmaceutical Company, Somerville, New Jersey; CIBA-GEIGY Corporation, Ardsley, New York; The Upjohn Company, Kalamazoo, Michigan. duodenum and anchored in place with sutures so as to permit intraduodenal administration of nutrients. Another polyethylene catheter was inserted through the jugular vein into the inferior vena cava between the heart and liver and secured with sutures. Either 2 $\mathrm{g} / \mathrm{kg}$ of glucose, $2 \mathrm{~g} / \mathrm{kg}$ of casein hydrolysate, both dissolved in water, or $3 \mathrm{~g} / \mathrm{kg}$ of peanut oil emulsified with $2 / 3$ of an egg yolk, were instilled over 15 minutes, 10 minutes after the start of an infusion of either saline alone or dehydrosomatostatin (SRIF) ${ }^{1}$ in saline (3.3 $\mu \mathrm{g} /$ minute), administered through catheters inserted in a lateral saphenous vein 30 minutes before the start of the experiment. All dogs were studied after an overnight fast in a fully conscious state. Experiments were carried out in pairs and in random order.

Blood specimens were obtained at frequent intervals from the jugular vein catheter and transferred into chilled tubes containing $500 \mathrm{U}$ of Trasylol (FBA Pharmaceuticals, New York) and $1.2 \mathrm{mg}$ of EDTA$2 \mathrm{Na}$ per $\mathrm{ml}$ of blood. Plasma glucose was determined by the glucose oxidase method using the Technicon Autoanalyzer (Technicon Instruments Corporation, Tarrytown, New York). Triglycerides were measured by the method of Kessler et al. [14]. $\alpha$-aminonitrogen was assayed by the method of Rosen [15]. Plasma insulin was measured by the method of Yalow and Berson [16], as modified by Herbert et al. [17].

${ }^{1}$ A gift of Dr. Roger Guillemin, Salk Institute, La Jolla, California. 
Pancreatic glucagon was assayed by means of a previously described and modified radioimmunoassay for glucagon [18], using antiserum 30K. Plasma GLI was determined, as previously described, by radioimmunoassay using antiglucagon serum $78 \mathrm{~J}$, which cross-reacts strongly with gut GLI [19].

\section{Results}

The Effect of Somatostatin on Plasma GLI, Insulin and Glucagon during Intraduodenal Administration of

\section{Glucose}

To determine the effects of somatostatin on glucose-induced GLI release, $2 \mathrm{~g} / \mathrm{kg}$ of glucose was instilled intraduodenally over a 15 minute period in a group of $4 \mathrm{dogs}$, beginning 10 minutes after the start of an infusion of either somatostatin $(3.3 \mu \mathrm{g} / \mathrm{min}$.) or a saline control for 160 minutes (Fig. 1). In the control experiments plasma GLI rose from $1.7 \pm 0.1$ to $4.2 \pm 0.4 \mathrm{ng} / \mathrm{ml}$ at 15 minutes $(p<0.02)$ and reached $5.0 \pm 0.4 \mathrm{ng} / \mathrm{ml}$ at 60 minutes $(p<0.01)$. In dogs receiving somatostatin, mean plasma GLI was significantly below the control value at 10,15 and $30 \mathrm{~min}$ after the administration of intraduodenal glucose $(p<0.025,<0.025$, and $<0.05)$, but increased gradu-

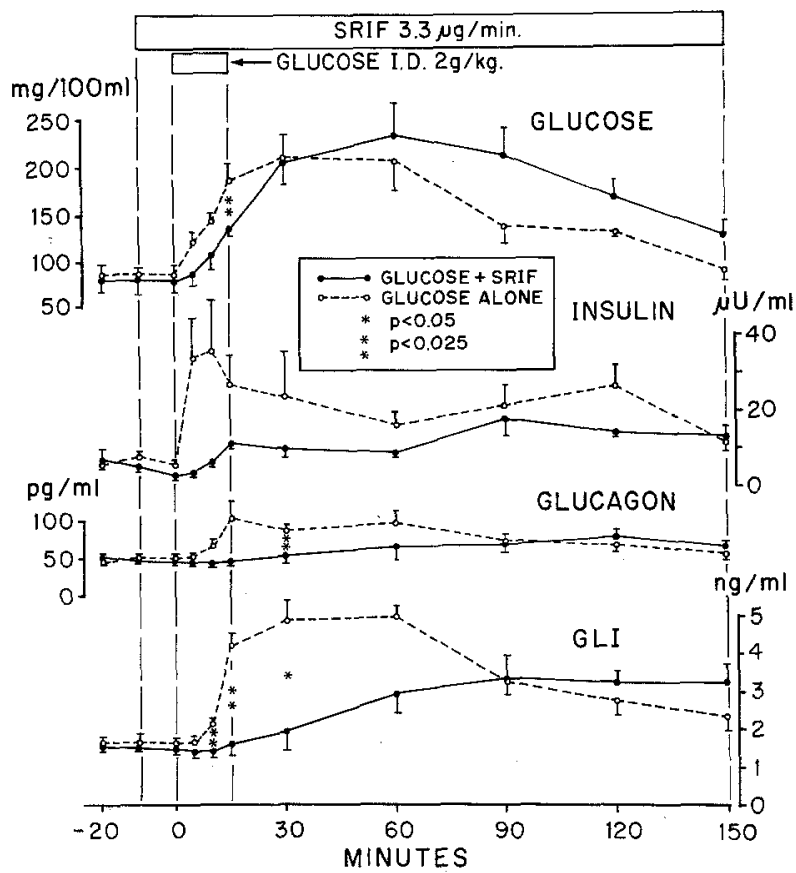

Fig. 1. The effects of somatostatin (SRIF) on the response of GLI, glucagon, insulin and glucose to an intraduodenal (I.D.) glucose load. Asterisks signify statistically significant differences between somatostatin treatment and the control experiment by paired $t$-test. Vertical bars represent \pm SEM. $n=4$

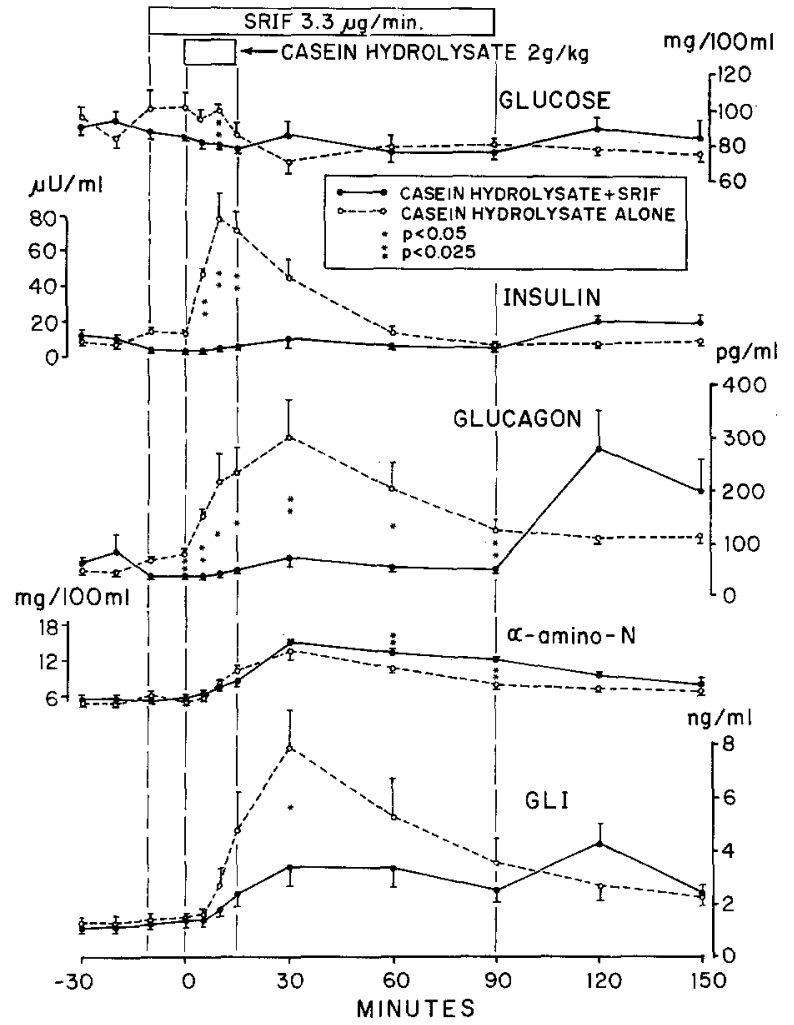

Fig. 2. The effect of somatostatin (SRIF) on the response of GLI $\alpha$-amino nitrogen, glucagon, insulin and glucose during an intraduodenal casein hydrolysate load. Asterisks signify statistically significant differences between somatostatin treatment and the control experiment by paired t-test. Vertical bars represent \pm SEM. $\mathrm{n}=4$

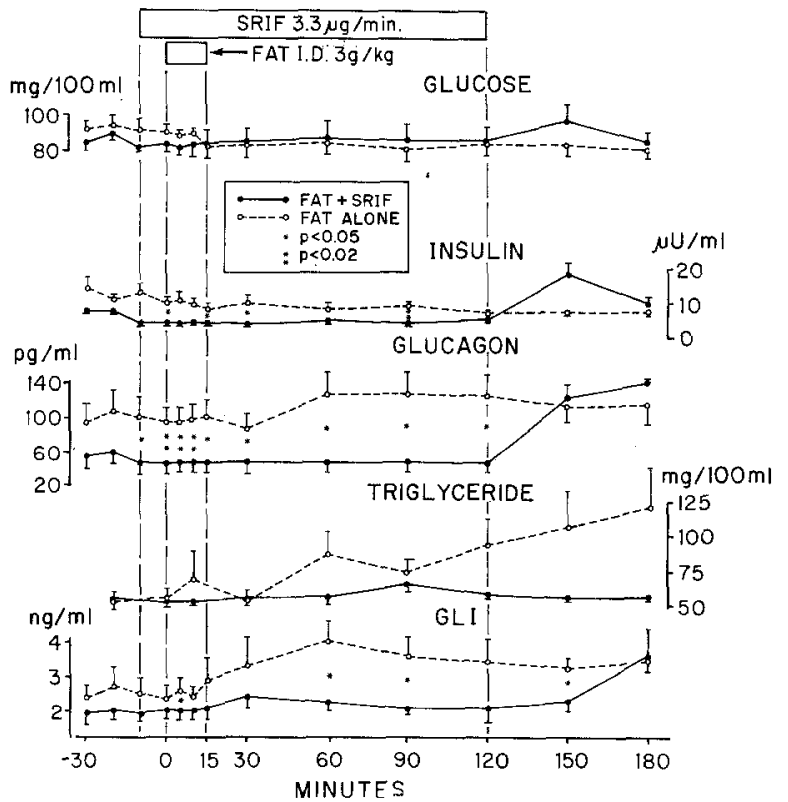

Fig. 3. The effect of somatostatin (SRIF) on GLI, triglyceride, glucagon, insulin and glucose response to an intraduodenal fat load. Asterisks signify statistically significant differences between somatostatin treatment and the control experiment by paired t-test. Vertical bars represent \pm SEM. $n=5$ 
ally after 30 minutes and rose to $3.4 \pm 0.6 \mathrm{ng} / \mathrm{ml}$ at 90 minutes. The rise in plasma glucose was delayed by somatostatin; mean plasma glucose was significantly below the control value at 15 minutes $(p<0.025)$, as reported in man [7]. Insulin and glucagon levels were below control values in the somatostatin infusion experiments.

The Effect of Somatostatin on Plasma GLI, Insulin and Glucagon Responses to Intraduodenal Casein Hydrolysate

To determine the effect of somatostatin on proteininduced GLI release, a group of 4 dogs was given 2 $\mathrm{g} / \mathrm{kg}$ of casein hydrolysate via an intraduodenal catheter during the intravenous infusion of either $3.3 \mu \mathrm{g} / \mathrm{minute}$ of somatostatin or saline control. In the control studies, a rise in GLI from $1.6 \pm 0.1 \mathrm{ng} / \mathrm{ml}$ to a peak of $8.0 \pm 1.4 \mathrm{ng} / \mathrm{ml}$ at 30 minutes was observed $(\mathrm{p}<0.005)$. During somatostatin infusion, this rise was reduced, averaging only $3.5 \pm 0.8 \mathrm{ng} / \mathrm{ml}$ at 30 minutes, significantly less than in the controls at this point $(\mathrm{p}<0.05)$. Somatostatin virtually abolished the rises in insulin and glucagon observed with casein alone (Fig. 2). Glucose levels were significantly below the control levels at 15 minutes $(p<0.025)$ and $\alpha$-amino nitrogen levels differed significantly at 60 minutes $(\mathrm{p}<0.025)$ in these experiments.

The Effect of Somatostatin upon GLI, Glucagon, Insulin and Triglyceride Levels Follogwing the Intraduodenal Administration of Long-Chain Triglycerides

To examine the effect of somatostatin upon the GLI response to a fat meal, $3 \mathrm{~g} / \mathrm{kg}$ of peanut oil emulsified with $2 / 3$ of an egg yolk was given intraduodenally to a group of 5 dogs (Fig. 3). In the control experiments, GLI rose from a baseline value of $2.4 \pm 0.3 \mathrm{ng} / \mathrm{ml}$ to a peak of $4.0 \pm 0.6 \mathrm{ng} / \mathrm{ml}$; somatostatin virtually abolished this rise, the mean values differing significantly from control experiments at 5,60,90 and 150 minutes by paired t-test $(\mathrm{p}<0.05)$.

Both glucagon and insulin levels were suppressed by somatostatin. No discernible differences were observed in glucose levels between somatostatintreated groups and controls. However, in the control experiments triglycerides increased from $54 \pm 7$ $\mathrm{mg} / \mathrm{dl}$ at zero time to a peak of $121 \pm 30 \mathrm{mg} / \mathrm{dl}$ at 180 minutes (N.S.) during somatostatin infusion, whereas triglyceride levels did not rise. Although there was no significant difference between the mean triglyceride levels in the somatostatin and control experiments at any point, the mean maximal triglyceride increment was significantly greater in the former group $(p<0.05)$, raising the possibility of reduced fat absorption.

\section{Discussion}

The rise in GLI that normally accompanies the absorption of nutrients is reduced or blocked during the simultaneous administration of pharmacologic doses of somatostatin. This adds another to the growing list of endocrine cells inhibited by somatostatin in large doses. Inhibition of insulin and glucagon secretion, frequently demonstrated in earlier studies $[4,5$, $6,7,20,21]$, was once again confirmed.

GLI blockade failed to modify the concentration of the absorbed nutrients. The lower mean glucose levels in the somatostatin-infused dogs during the first 30 minutes of glucose absorption is statistically significant, and one might postulate a greater net uptake of absorbed glucose by the liver consequent to a reduction in GLI-induced glycogenolysis [13, 22]. This is a not unreasonable hypothesis compared with alternative possibilities; it seems less likely that somatostatin improved glucose tolerance by slowing glucose absorption, or that glucose uptake by liver or peripheral tissues increased in the face of reduced insulin secretion. However, the greater suppression of glucagon during glucose absorption plus somatostatin might have been the cause of the early reduction in plasma glucose. It should be stressed that the apparent lack of glucagon suppression during glucose absorption in the control dogs of this study does not mean that pancreatic glucagon secretion did not decline in the pancreaticoduodenal vein. Repeated studies have demonstrated that glucagon secretion is suppressed during the absorption of glucose $[9,23,24]$. The 50 $\mathrm{pg} / \mathrm{ml}$ glucagon rise noted in the control experiments of Fig. 1 is believed to reflect the $2 \%$ crossreactivity of antiserum $30 \mathrm{~K}$ with GLI, which had risen about 2.5 $\mathrm{ng} / \mathrm{ml}$ at that point.

The failure of triglycerides to rise during a fat load in somatostatin treated dogs may also be significant, although the statistical difference from the controls was marginal. It could reflect reduced exocrine pancreatic and gall bladder function [25], secondary to blockade of the secretion or the effect of gut hormones such as pancreozymin-cholecystokinin.

\section{References}

1. Brazeau, P., Vale, W., Burgus, R., Ling, N., Butcher, M., Rivier, J., Guillemin, R.: Hypothalamic polypeptide that inhibits the secretion of immunoreactive growth hormone. Science 179, 77-79 (1973) 
2. Siler, T.M., Vandenberg, G., Yen, S.S.C., Brazeau, P., Vale, W., Guillemin, R.: Inhibition of growth hormone release in humans by somatostatin. J. clin. Endocr. 37, 632-634 (1973).

3. Siler, T. M., Yen, S.S. C., Vale, W., Guillemin, R.: Inhibition by somatostatin of the release of TSH induced in man by thyrotropin releasing factor. J. clin. Endocr. 38, 742-745 (1974)

4. Alberti, K.G.M.M., Christensen, N.J., Christensen, S.E., Hansen, A.P., Iversen, J., Lundbaek, K., Seyer-Hansen, K., Orskov, H.: Inhibition of insulin secretion by somatostatin. Lancet 1973 II, 1299-1301

5. DeVane, G. W., Siler, T.M., Yen, S.S.C.: Acute suppression of insulin and glucose levels by synthetic somatostatin in normal human subjects. J. clin. Endocr. 38, 913-915 (1974).

6. Koerker, D.J., Ruch, W., Chideckel, E., Palmer, J., Goodner, C. J., Ensinck, J., Gale, C.C.: Somatostatin: hypothalamic inhibitor of the endocrine pancreas. Science 184, 482-484 (1974)

7. Mortimer, C.H., Turnbridge, W.M.G., Carr, D., Yeomans, L., Lind, T., Coy, D.H., Bloom, S. R., Kastin, A., Mallinson, C.N., Besser, G.M., Schally, A.V., Hall, R.: Effects of growth hormone release inhibiting hormone on circulating glucagon, insulin, and growth hormone in normal, diabetic, acromegalic, and hypopituitary patients. Lancet 1974 I, 697-701

8. Bloom, S. R., Mortimer, C.H., Thorner, M.O., Besser, G.M., Hall, R., Gomez-Pan, A., Roy, V.M., Russell, R.C.G., Coy, D.H., Kastin, A.J., Schally, A.V.: Inhibition of gastrin and gastric-acid secretion. Lancet 1974 II, 1106-1109

9. Unger, R.H., Ohneda, A., Valverde, I., Eisentraut, A.M., Exton, J.: Characterization of response of circulating glucagon-like immunoreactivity to intraduodenal and intravenous administration of glucose. J. clin. Invest. 47, 48-65 (1968)

10. Böttger, I., Dobbs, R., Faloona, G. R., Unger, R.H.: The effects of triglyceride absorption upon glucagon, insulin, and gut glucagonlike immunoreactivity. J. clin. Invest 52, 2532-2541 (1973)

11. Unger, R.H.: Glucagon-like immunoreactivity (GLI or enteroglucagon). Proceedings of the Fourth International Congress of Endocrinology. pp. 520-524. Amsterdam: Excerpta Medica 1972

12. Böttger, I., Faloona, G.R., Unger, R.H.: The effect of calcium and other salts upon the release of glucagon-like immunoreactivity from the gut. J. clin. Invest. 51, 831-836 (1972)

13. Sasaki, H., Rubalcava, B., Baetens, D., Blázquez, E., Srikant, C.B., Orci, L., Unger, R.H.: Identification of glucagon in the gastrointestinal tract. J. clin. Invest (in press) (1975)

14. Kessler, G., Lederer, H.: Automation in analytical chemistry. (ed. L.T. Skeggs, p. 341. New Jersey: Mediad 1965
15. Rosen, H.: A modified ninhydrin colorimetric analysis for amino acids. Arch. Biochem. 67, 10-15 (1957)

16. Yalow, R.S., Berson, S.A.: Immunoassay of endogenous plasma insulin in man. J. clin. Invest 39, 1157-1175 (1960)

17. Herbert, V., Lau, K. S., Gottlieb, C.W., Bleicher, S. J.: Coated charcoal immunoassay of insulin. J. clin. Endocr. 25, 1375-1384 (1965)

18. Faloona, G.R., Unger, R.H.: Glucagon. In: Methods of hormone radioimmunoassay (eds. B.M. Jaffe, H. R. Behrman) pp. 317-330. New York: Academic Press 1974

19. Eisentraut, A. M., Ohneda, A., Parada, E., Unger, R.H.: Immunologic discrimination between pancreatic glucagon and enteric glucagon-like immunoreactivity (GLI) in tissues and plasma. (Abstract). Diabetes 17 (Supp. 1), 321-322 (1968)

20. Gerich, J.E., Lorenzi, M., Schneider, V., Kwan, C. W., Karam, J.H., Guillemin, R., Forsham, P.H.: Inhibition of pancreatic glucagon responses to arginine by somatostatin in normal man and in insulin dependent diabetics. Diabetes 23, 876-880 (1974)

21. Sakurai, H., Dobbs, R., Unger, R.H.: Somatostatin-induced changes in insulin and glucagon secretion in normal and diabetic dogs. J. clin. Invest. 54, 1395-1402 (1974)

22. Valverde, I., Rigopoulou, D., Marco, J., Faloona, G. R., Unger, R.H.: Characterization of glucagon-like immunoreactivity (GLI). Diabetes 19, 614-623 (1970)

23. Müller, W.A., Faloona, G.R., Aguilar-Parada, E., Unger, R.H.: Abnormal alpha-cell function in diabetes. New Engl. J. Med. 283, 109-115 (1970)

24. Heding, L. G., Rasmussen, S.M.: Determination of pancreatic and gut glucagon-like immunoreactivity (GLI) in normal and diabetic subjects. Diabetologia 8, 408-411 (1972)

25. Creutzfeldt, W., Lankisch, P.G., Fölsch, U.R.: Hemmung der Sekretin- und Cholezystokinin-Pankreozymin-induzierten Saft- und Enzymsekretion des Pankreas und der Gallenblasenkontraktion beim Menschen durch Somatostatin. Dtsch. med. Wschr. 100, 1135-1138 (1975)

R.H. Unger, M.D

Prof. of Internal Medicine

Director of Research

Veterans Administration

Hospital

Dept. of Internal Medicine

5323 Harry Hines Boulevard

Dallas, Texas 75235

USA 